\title{
Natural and anthropogenic hazards in karst areas of Albania
}

\author{
M. Parise ${ }^{1,2}$, P. Qiriazi ${ }^{3}$, and S. Sala ${ }^{4}$ \\ ${ }^{1}$ National Research Council, IRPI, Via Amendola 122-I, Bari, 70125, Italy \\ ${ }^{2}$ Gruppo Puglia Grotte (Castellana-Grotte, BA), Italy \\ ${ }^{3}$ Department of Geography, University of Tirana, Rruga e Elbasanit, Tirana, Albania \\ ${ }^{4}$ Geography Study Center, Rruga M. Toptani 13, Tirana, Albania
}

Received: 28 July 2004 - Revised: 5 October 2004 - Accepted: 6 October 2004 - Published: 8 October 2004

Part of Special Issue "Natural and anthropogenic hazards in karst areas"

\begin{abstract}
In Albania, about one quarter of the country is occupied by outcroppings of soluble rocks; thus, karst represents an important and typical natural environment. Today karst areas are seriously threatened by a number of hazards, of both natural and anthropogenic origin. Many problems are related to agricultural practices: the use of heavy machinery, ever-increasing in recent years, results at many sites in destruction of the original karst landscapes. Use of pesticides and herbicides, in addition, causes the loss of karst ecosystems of great biological relevance, as has been observed in the Dumre district, where about 80 lakes of karst origin are present in the evaporites of Permian-Triassic age. Agricultural practice performed on slopes with medium to high gradient is a further factor which greatly predispose the slopes to erosion. The cave heritage of Albania (estimated so far in about 1000 caves) is at risk because of the uncontrolled quarrying activities which determine the total or partial destruction of karst caves, including many of naturalistic, archaeological and speleological interest. Many caves have also become sites of illegal disposal of solid and liquid wastes, which causes pollution of the karst ecosystems and of the aquifer therein present, with heavy negative consequences on the quality of water. Even though most of the cases here mentioned are related to anthropogenic activities, the natural hazards, such as subsidence phenomena, floods, and the development of sinkholes, have not to be disregarded.
\end{abstract}

\section{Introduction}

Albania is characterized for about $23 \%$ of its extension by soluble rocks (carbonates and evaporites; Fig. 1), which makes karst a very important and typical natural environment in the country. Today karst areas are seriously threatened by a number of natural and anthropogenic hazards, and heavy degradation or pollution events have already been registered

Correspondence to: $\mathrm{M}$. Parise

(m.parise@ba.irpi.cnr.it) over large areas of the albanian territory. The recent socioeconomical history of Albania, and the military conflicts occurred in the last decades in the Balkans, have furthermore exacerbated a situation which, due to its natural features, was already highly fragile. Karst areas are well known, in fact, as a very peculiar environment where any negative action performed at the surface may rapidly be transferred in depth and/or over large areas. Geological, morphological, and hydrogeological features of karst landscapes make them highly vulnerable to a variety of degradation and pollution problems (Williams, 1993; Parise and Pascali, 2003). Pollution actions are very easy to be performed, whilst, on the other hand, recovery of the originary condition is very difficult to be reached, and sometimes impossible. Management of karst territories, therefore, appears to be a quite complicated matter. Developing countries, as well as regions coming out from wars or periods of strong economical changes, in turn, have to face even more complicated situations.

Albania is quite a small country (area $28748 \mathrm{~km}^{2}$ ), which, in contrast with its size, hosts most of the above mentioned negative features, namely the fragility of the natural environment, together with a complex recent history, including as main steps the fall of the communist government in 1991, and the later opening to free market, with the beginning of the so-called transitory period. Without entering the social, economical and historical matters, this paper intends to briefly examine the main natural and anthropogenic hazards in the karst of Albania. Inevitably, however, when dealing with the anthropogenic hazards, some mention will be done to recent history.

\section{Karst areas of Albania}

About one quarter of the albanian territory is characterized by outcroppings of soluble rocks, ranging in lithology from limestones, to chert limestones, and subordinate dolostones of Trias-Paleogene age, to evaporites (Permian-Trias and Messinian). The outcrop percentage of soluble rocks 


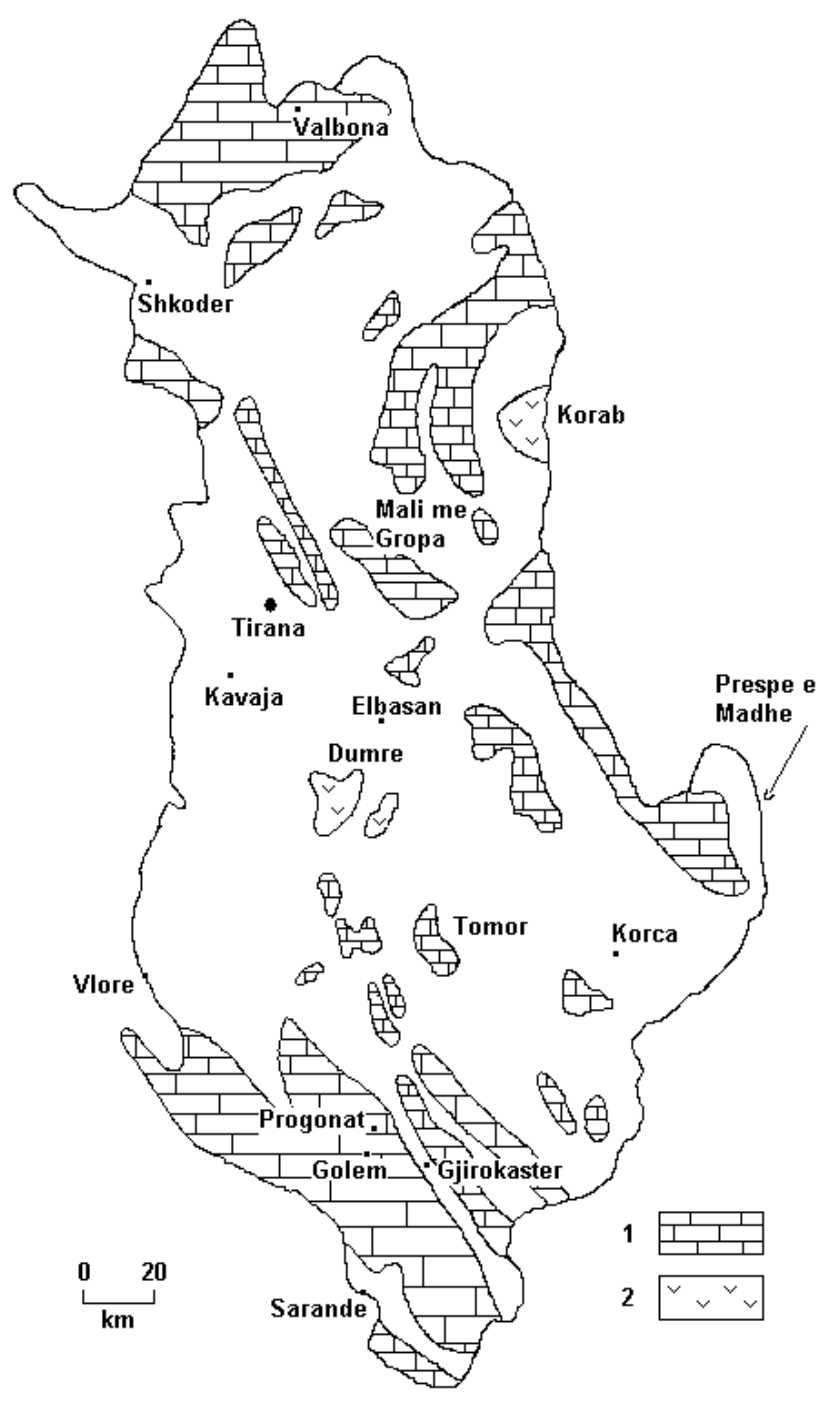

Fig. 1. Sketch map of karst areas of Albania, showing the main localities cited in the text: 1) carbonate rocks; 2) evaporite rocks.

becomes still higher if the wide coastal plains of the country, characterized by alluvial sediments, are not taken into account. Two main phases of karst can be identified in Albania: the ancient karst, which started from Oligocene - Miocene at the moment of the main land emersion and went on until Pliocene (ancient karst morphologies are, for example, the planation surfaces at the Kurvelesh Mountain); and the socalled young karst, acting from Pliocene up to the present (Kristo et al., 1987). The last phase, still active today, is the most important and has produced most of the landforms today recognizable. The great variety of karst landforms in Albania may be differentiated in three main categories, based upon the geological-structural setting, the morphology, and the climate (Qiriazi, 2001; Parise et al., 2003): i) lowelevation karst, mainly present in south-western Albania, at the boundary with Greece; ii) high mountain karst, even with morphologies related to glacio-karstic processes; iii) classical mediterranean karst, with great diffusion of surface karst

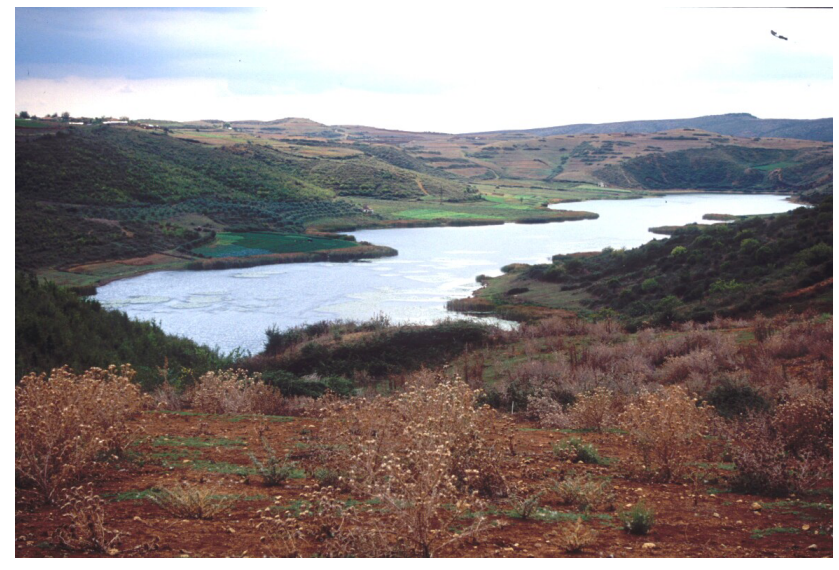

Fig. 2. View of lake Deges the largest among the about 80 karst lakes in the Dumre district.

landforms, and which present evolution is controlled by the pluviometric regime.

The Albanian Alps, in northern Albania, are the most significant example of high mountain karst: they are a very rugged chain, which reach the maximum elevation over $2600 \mathrm{~m}$ a.s.l. at Mount Ismet, south of Valbona. The other carbonate chains and massifs of the country are generally elongated in NW-SE direction, and belong to the category of the classical mediterranean karst: this is the case, among many others, of Mali me Gropa, Dajti Mountains, and Tomor-Polisit in central Albania (Sala et al., 1994), and of the Kurvelesh Massif which characterizes southern Albania, with its prolongation of Mali I Gjere, south of Gjirokaster. At Kurvelesh, a great density of surficial karst landforms may be observed, which include karst microforms such as karrenfields and kamenitza, and larger landforms as dolines and uvalas (Krutaj, 1985). These landforms also characterizes Mali me Gropa, where a great number of enclosed depressions and dolines are the main geomorphological features recognizable at the surface. The name itself Mali me Gropa (which means Mount of the Holes) indicates the high frequency of dolines, comparable to what occurs in other areas of the Mediterranean karst (Baboci et al., 1991). In the south, there is also the most interesting area as regards coastal karst, from the southern limit of the Gulf of Vlore down to the southernmost tip of Albania at Mali I Saraqinit.

In addition to carbonates, Albania hosts further karst areas developed in the evaporites of Permian-Triassic age, and in those of Messinian age as well (Diamnti, 2002; Qiriazi et al., 2004). As regards the most ancient evaporite rocks, the main areas of interest are Mount Korab, near Peshkopi, at the boundary with Macedonia, and the Dumre district in central Albania (Fig. 1). The latter is a diapir, comprised within an area with trans-extensional transverse tectonics (Aliaj, 1999); due to age of evaporites, and intense weathering and erosion, the landscape is mostly tabular, with a few residual hills, remnants of the ancient morphology. The main karst landforms are some 80 karst lakes (Kristo, 1994), which 
formation is related to the presence of thick deposits of residual clays and terre rosse (Fig. 2). Messinian evaporites are present in the Kavaja area, west of Tirana, producing a quite different landscape. The evaporites crop out along a narrow, NW-SE elongated, strip at the contact with Pliocene sands and clays. In this case, several caves are present in the evaporitic rocks, mostly with sub-horizontal development (Bassi et al., 1999; Qiriazi et al., 2004).

\section{Natural hazards}

Natural hazards in karst areas of Albania include floods, landslides, sinkholes, and subsidence phenomena. As floods and mass movements have been the object of several dedicated articles (see for example, Qiriazi and Sala, 1999) attention will be focused on subsidence and sinkholes, which represent a significant geohazards in Albania, as well as in many other parts of Europe (Cooper and Waltham, 1999; Gutierrez et al., 2001; Cooper, 2002; Delle Rose and Parise, 2002; Guerrero et al., 2004).

Subsidence phenomena in Albania mostly derive from the neotectonic evolution of the region, characterized by a general uplift that began after the Pliocene (Aliaj et al., 2001). From the Middle Pleistocene, several periods of subsidence have occurred, resulting in the formation of graben structures, occupied by lakes such as Shkodra, Ohrid and Prespa, or by plains as at Korça, Elbasan and Zadrima. Many of these areas are located in karst environments, or in tectonic settings where soluble rocks also crop out. The graben structures produced by neotectonics have been often filled with Quaternary alluvial sediments, which may reach up to $200 \mathrm{~m}$ in thickness. At many sites, these deposits represent significant aquifers which, in the course of the recent demographic expansion of Albania have been intensively exploited. This caused significant land subsidence due to draw down of the water table. For example in the Korça plain subsidence of about $700 \mathrm{~mm}$ has been estimated after 10 years of pumping in the Turani well field with a withdrawal rate of 500 1/s (Eftimi and Tafilaj, 1999).

The development of sinkholes is diffuse in karst areas of Albania. Sinkholes may form in karst due to the presence of underground cavities and conduits, or to settlements of filling deposits of ancient caves (Williams, 2003; Delle Rose et al., 2004). Even generally a natural process, in many cases their development may be favoured and/or accentuated by human activities. Sinkholes produced by collapse of the vault of underground cavities are quite diffuse in karst areas of Albania, and generally they do not cause any problem when occurring in mountains or in scarcely populated areas. In other, more populated, settings the development of sinkholes may create severe problems: this is the case, for example, of the Dumre district. In recent years, repeated cases of sinkholes have occurred there, with initial formation of a depression, and later evolution through enlargement of the original feature (Fig. 3). The usual way to face the problem, in the attempt to avoid danger to nearby human activities and buildings, is fill-

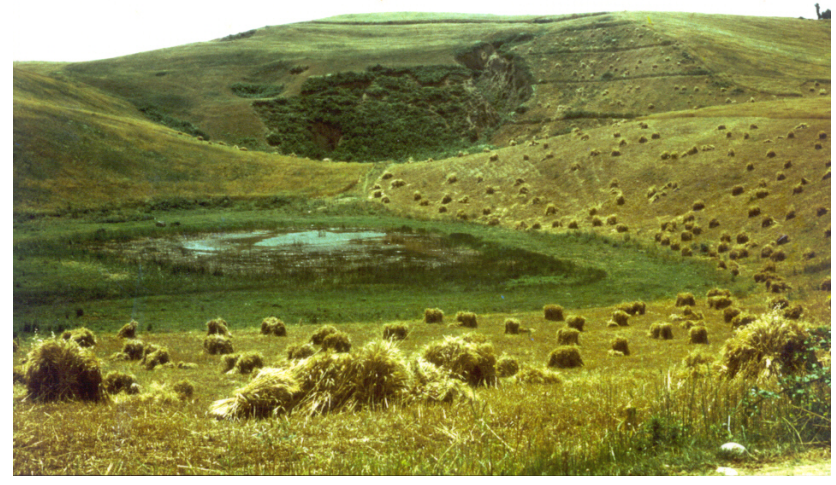

Fig. 3. Sinkhole in the Permian-Triassic evaporites of the Dumre district. The sinkhole, which developed in few hours during 1998, had a depth of about $30 \mathrm{~m}$. Note the presence of open cracks at the margins of the sinkhole, testifying its progressive widening.

ing the resulting depression with solid materials and earths. However, it is doubtful if such a practice really has positive effects; when the sinkhole develops due to presence of underground cavities (even if these are located at depth greater than $10 \mathrm{~m}$ ) the load exerted by the filling materials might in fact result in favouring the sinkhole evolution.

At Dumre, and at other areas where evaporites also crop out extensively, there is the need to better study the karstification in the Permian-Triassic gypsum formations in order to gain a better understanding of both paleokarst and active karst history, and to correctly evaluate likely problems of applied geology, as learned from other parts of Europe (Gutierrez, 1996).

\section{Anthropogenic hazards}

\subsection{Land degradation and desertification}

Land degradation, and partial or total destruction of the karst landscape, up to desertification, are among the most serious hazards that Albania has to face in karst environments. Desertification, as defined by the United Nations Environment Programme, is "land degradation in arid, semi-arid and dry sub-humid areas resulting from various factors including climatic variations and human activities" (UNEP, 1990). Specifically, "land degradation" means reduction and loss of the biological and economic productivity caused by land-use change, or by a physical process or a combination of the two. Some Authors further incorporate in the above definition also processes such as rural depopulation, given the importance that desertion of rural areas is having in many European countries (Thornes, 2002). Land degradation and desertification strongly affect Albania, with particular regard to karst areas, which suffered serious problems during the Communist period, when wide sectors of the natural karst landscape were used for agricultural purposes without considering the naturalistic, geomorphological and ecological peculiarity of 


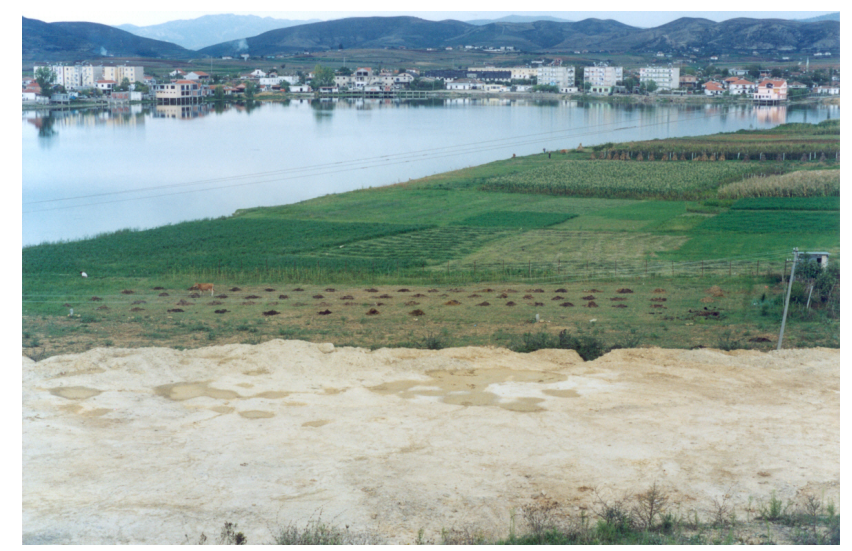

Fig. 4. Partial view of the Belsh lake, in the Dumre district. The water was once used as drinkable water, but later development of the town of Belsh (at the lake margin), and intensive use of herbicides and pesticides for agricultural practice in the surrounding areas, resulted in heavy pollution, and degradation in the quality of water.

these environments. Karst landforms such as polje, dolines and uvala have been often transformed into arable fields; the main products of agriculture were cereals, especially wheat and corn, tobacco and potatoes.

As in other regions of the Mediterranean basin (Tulipano et al., 1982; Sauro, 1993; Atalay, 1999; Nicod and Salomon, 1999), the problem was not the agricultural use of karst areas in itself, but rather some operations which resulted in irrevocable destruction of the soil structure, in erosion, and in polluting events: namely, the practice of stone clearing, and the intense and uncontrolled use of pesticides and herbicides. Stone clearing has actually become the most diffuse practice to gain new lands to agriculture (Akdim and Amyay, 1999; Burri et al., 1999). In past times, stones were cleared from the fields by hand, while the resulting detritus was generally used to build dry walls for protection, enclosures, or terrace support. All of this was realized in a "sustainable" way, in the attempt to maintain an equilibrium between the human activities and the natural environment. New agricultural technologies, and namely the advent of machinery for stone clearing, have caused in recent years, on the other hand, an enormous acceleration in the process of land use change. This was generally carried out without considering the likely negative consequences for the karst environment. Even though stone clearing practice in Albania is not yet comparable to what happens, for example, in the Murge Plateau of central Apulia, in southern Italy (Giglio et al., 1996; Parise and Pascali, 2003), the overall result is in any case negative in terms of loss of the karst landscape. In the most recent years, in addition, the wider use of machinery is still increasing the amount of land cleared of the calcareous stone. This practice, if carried out without control and not preserving at least partly the soil cover, may strongly favour the development of erosional processes (Gerrard, 1992), which effects become particularly significant with the increase in slope gradient.
The absorpion capacity of soil and bedrock decreases, while, on the other hand, the surface runoff is favoured. When the gradient allows concentration of the surface runoff, rill erosion begins, which may rapidly evolve to development of gullies with increasing erosion. An heavy increase in erosion (areal as well as linear) has thus to be registered.

A further problem related to agriculture is the extensive use of pesticides and herbicides which was favoured by the complete absence of control for many years, and, still today, by lack in organization of the offices which should perform this control. As a result, very serious consequences and negative impacts on the natural environment were registered, with loss of flora and fauna typical of karst areas. One of the most significant example is probably the district of Dumre and the karst lakes there present. Many of these have been exploited for irrigation without any limiting thresholds, thus lowering their levels under critical values, i.e. the biological minimum. This reduced their natural beauty and created big ecological stresses leading to the disappearance of many species (Qiriazi and Sala, 2000).

Water from the lakes was intensively used for irrigation in the past tens of years, irrespective of the effects on the biota environment. Some of the smallest lakes were reclaimed, and typical marshlands were canceled, together with the fauna living in them. In addition, agricultural practices were performed closer and closer to the lakes, until reaching their very boundaries. Attempts in cultivate also sectors with high slope gradients resulted in promoting erosion from the slopes and deposition of materials into the lakes. This especially occurred at the end of the summer and the beginning of the fall seasons, when rainfalls typically concentrate with greater intensity.

As a further effect of the intense agricultural practice carried out close to the lakes, deterioration in the quality of water had to be registered: the waters were used, until 3040 years ago, as drinkable hydric resource, but in the recent years the low quality of water caused it to not be drinkable any more.

Pollution is furtherly indicated by loss of many fish species which once populated the lakes. Specially for the lakes located nearby villages, such as the case for Belsh Lake (Fig. 4), at the homonymous village, the level of pollution seems to be particularly bad, due to discharge of liquid waste, likely including chemicals, in the lake. Unfortunately, no data are available to control the type and amount of polluting substances, and, to our knowledge, no monitoring of the quality of water has started.

As in many other countries of the Mediterranean basin, land-use changes during the recent history of Albania are due to a combination of physical factors and socio-economic reasons. Land mismanagement is very frequent, and negative impacts deriving from human activities and extensive agriculture are extremely common. Many attempts have been made, for example, to extend cultivated areas at the expenses of forest lands, which implies high ecological alterations due to deforestation and the break-up of the original equilibrium between cultivation, grazing and forestry (Gillieson 
and Thurgate, 1999; Kosmas et al., 2002). During the Communist period, large forested sectors of Albania were cut, and antiquated technological industry, causing high levels of pollution, were used. Lack of laws protecting the natural environment furtherly increased the damage: about 300000 ha of bush woods and forests were replaced by cultivated land. After that time, however, the situation did not improve: during the transitory period, the forest damage continued, even at a faster pace than before. This was mostly due to large illegal cuttings. If we combine this with overgrazing, the use of woods for illegal constructions, contraband trade of lumber, and wildfires (840 cases registered in Albania in 1997, 600 cases in 1998), a very bad figure appears (Qiriazi and Sala, 2000).

The land covered by forest reduced from 1400000 ha in 1944 to 1045000 ha in 1995 (Fig. 5). The reduction is still going on, but we do not have any specific, more updated, figure. However, if we consider that in 2002 a total of 1051050 hectares has been assessed for both forest and pasture in $\mathrm{Al}-$ bania, it can be easily estimated a further great reduction in forests. The loss of forests, in itself a symptom of land degradation, is still more serious in karst areas, a setting particularly fragile and sensitive to any change in the global ecosystem. The effects, especially in rural and mountain areas, may be not very visible but, in the long run, result in serious consequence.

As observed by Dunne (2001), the hydrologic and geomorphic changes resulting from alterations to the land surface and canopy cover in forest lands are subtler than those occurring in urban areas (Dunne, 2001, p. 77). Nevertheless, these changes have significant effects on runoff, erosion, water quality degradation, and loss of biological species.

Reduction or loss of forested areas are also related to wildfires and/or to overgrazing. As regards these latter topics, an interesting comparison may be made between the Albanian territory and the island of Sardinia, in western Italy. Sardinia in fact shares many common features with karst areas of Albania, as regards both lithologies and physiography, and agro-pastoral activities. Livestock farming is one of the main economic activities in Sardinia, and this has heavy consequences on land degradation of the region. The agro-pastoral activities are a major cause of fires most of which are started deliberately, since the fire is considered an important practical and economical tool for clearing lands for grazing (Enne et al., 2002). This practice, which immediate effects are the destruction of the vegetative cover, and negative effects on the underlying soil, leading to increased erosion, combine with overgrazing to produce severe land degradation (Holland, 1994; Manzano and Navar, 2000).

Overgrazing, in turn, has many negative effects on the environment. Grazing involves biting, pulling and breaking off plant parts, which cause defoliation, or even pulling entire plants out of the ground, if they are not well rooted (Enne et al., 2002). In addition to removal of organic matter from the soil and reduction of vegetation, grazing also causes soil compaction by hooves, which reduces the porosity of the soil and, in turn, the capability of water to infiltrate and percolate

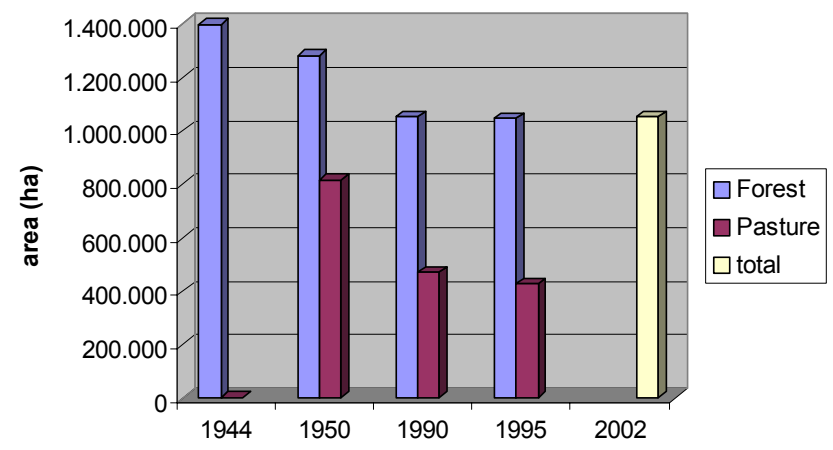

Fig. 5. Area occupied by forest and pasture in Albania from 1944 to 2002 (no data available for pasture in 1944; 2002 data provides only the total area, with not distinction between forest and pasture). Modified after Haska et al. (2003).

into the soil. Even with low gradient, this causes increased water runoff, promoting erosion.

As in Sardinia, loss of forests and soil degradation in Albania are very complex processes which include environmental problems, decrease or loss of productive capacity of soil, etc., also due to a number of anthropogenic activities. In the last decades, the growing demand for new cultivable lands caused an increase in the total area for agriculture from 290000 ha in 1938 to over 700000 ha in 1990 (Table 1). For this purpose, forests have been cut and marsh land has been reclaimed. Many marsh lands in the western lowland have been dried and new fields on hilly and mountainous slopes opened, even in slaty slopes by cutting shrubs and woods. The agriculture was first mainly oriented in cereals and subsequently in industrial plants like cotton or tobacco. This re-orientation seriously damaged the original ecosystems with high ecological values and resulted in damaged plants and reduced biodiversity, again intensified erosion and land degradation (Qiriazi and Sala, 2000).

Few data on erosion are available in Albania; however, it is clear that in the last decades millions of tons of nutrient-rich topsoil have been washed away, strongly increasing the rate of erosion and producing land degradation, even desertification in some areas. A direct consequence of land degradation is the high vulnerability to floods, especially in those areas where watershed management appears to be inadequate (i.e. north-western Albania). It is well known that floods in karst environments may be particularly insidious, and produce severe damage; this is due to peculiar hydrologic features of karst areas, combined with modification of the landscape performed by man (Parise, 2003).

Available data indicate that soil erosion in Albania ranges from 10 to 20 ton/ha/year, and in some cases it reaches values of 70 ton/ha/year (Table 2). Soil loss along streams and rivers is estimated in some tenth hectares per year, while the land susceptible to mass movements is estimated in about 10000 ha (Kovaci et al., 2003). These numbers are well comparable with erosion rates measured in other Mediterranean areas: for example, the rates of erosion in badlands from eastern 
Table 1. Areas of arable land, forest pastures (in thousands ha) and population (thousand inhabitants). Source: Statistical year book of Albania (1993); simplified after Qiriazi and Sala (1999).

\begin{tabular}{llllllll}
\hline & 1938 & 1950 & 1960 & 1970 & 1980 & 1982 & 1990 \\
\hline Total area & 290.0 & 391.2 & 457.0 & 599.0 & 702.0 & 714.2 & 704.0 \\
Field corps & - & 374.0 & 417.0 & 512.0 & 585.4 & 589.8 & 579.0 \\
Orchards & - & 3.2 & 15.0 & 30.0 & 55.7 & 59.6 & 60.0 \\
Vineyards & - & 2.6 & 8.0 & 12.0 & 17.7 & 20.3 & 20.0 \\
Olives & - & 11.4 & 17.0 & 36.0 & 43.4 & 44.5 & 45.0 \\
Forests & - & 1282.0 & 1293.0 & 1233.0 & 1024.0 & 1048.0 & 1002.0 \\
Pastures & - & 816.0 & 777.0 & 631.0 & 416.0 & 443.0 & 403.0 \\
Population & 1003.0 & 1215.2 & 1607.3 & 2135.6 & 2670.5 & 3138.1 & 3255.9 \\
\hline
\end{tabular}

Table 2. Quantity of eroded soil by river discharges. Source: Institute Hydrométéorologique (1985). Simplified after Qiriazi and Sala (1999).

\begin{tabular}{lll}
\hline River & Area of basin $\left(\mathrm{km}^{2}\right)$ & Erosion (ton/ha/year) \\
\hline Drini & 11756 & 15.43 \\
Mati & 2441 & 13.30 \\
Ishmi & 673 & 40.50 \\
Erzeni & 760 & 55.00 \\
Shkumbini & 2444 & 32.20 \\
Vjosa & 6706 & 15.80 \\
Semani & 5649 & 30.80 \\
\hline
\end{tabular}

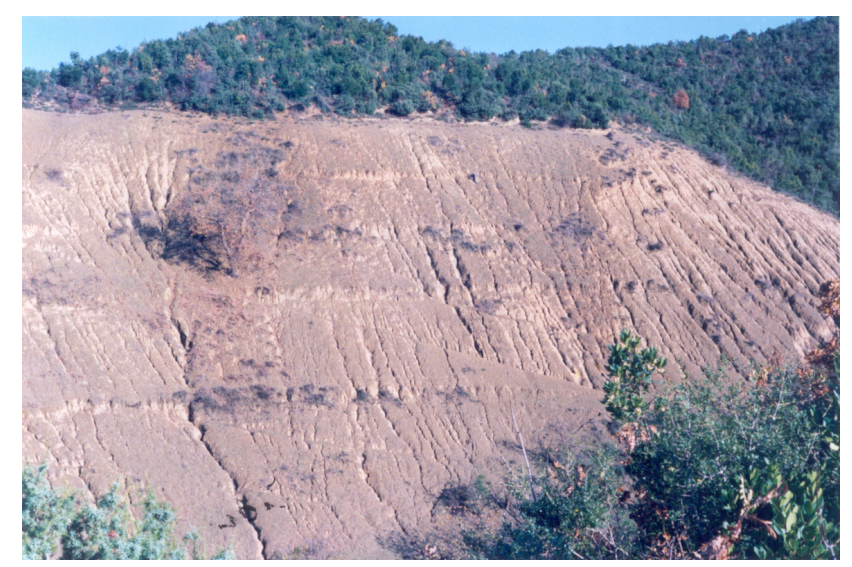

Fig. 6. Slope in the Gramsh area, south of Elbasan: the slope in flysch deposits, originally covered by vegetation, was used for agricolture practice, with the farm tractors working along the steepest slope gradient. This resulted in development of rills and gullies, which in turn forced the farmers to abandon the slope.

and western Europe vary from 0.4 to $1.7 \mathrm{~mm} /$ year (Yair et al., 1982; Benito et al., 1992).

The natural phenomenon of soil erosion is exacerbated in many areas of Albania. The climatic conditions and the high susceptibility to erosion of the materials (which by themselves create a high to very high potential for erosion) have to

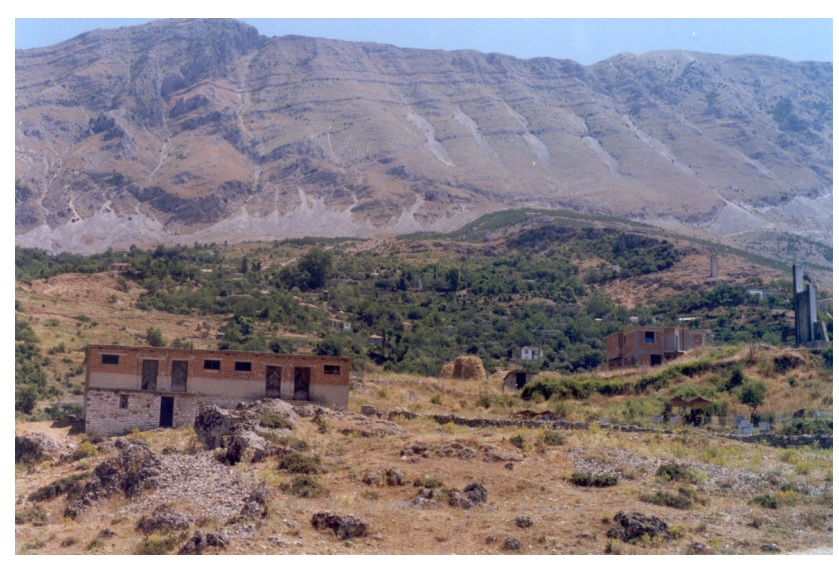

Fig. 7. Tectonic contact between flysch and conglomerates (in the foreground) and limestones which form the backbone of Mali $i$ Gjere (in the background), near Gjirokaster. Until 40 years ago, the limestone mountains were covered by thick forests. Wood cutting and wildfires were extremely diffuse in the area in the last tens of years, and the lack of tree cover promoted intense erosion, with great production of debris which fed the talus cones visible at the footslopes.

be coupled with the topography of the region, and with landuse practices as well. The latter, in particular, may be responsible for increasing of the erosion, especially when farmers cultivate steep slopes using machinery which open the way to development of linear erosion, through the formation of rills and gullies (Fig. 6).

Agricultural practices and land-use change work also in favouring a quite high susceptibility of the terrains to mass movements in Albania. The natural geological setting of the country has, in fact, a prominent role in predisposing the terrain to erosional and landsliding activity, especially at the contact areas between soluble rocks and terrigenous deposits (Fig. 7): to provide a few examples, the contact zone between flysch and carbonate rocks in the Albanian Alps, the western edge of the Kruja carbonate platform passing to molasses and flysch formations, the Korab limestones at contact with Paleozoic schists. In most of these cases, selective erosion combined with the main tectonic lines controlled 
the morphological definition of the valley and mountains systems, and the consequent development of erosional processes.

To summarize, there are many anthropogenic reasons which may be invoked for favouring intense erosion and, more generally, land degradation in Albania; the main are listed as follows:

- ploughing on steep slopes;

- clearing of shrubs and forests;

- use of antiquated technologies in land cultivation;

- practice of stone clearing;

- intensive exploitation of the soil;

- intensive exploitation of underground water for irrigation.

\subsection{Groundwater pollution}

The rapid growth in urban population and water demand in the last few decades have resulted in greatly increased watersupply provision and in wastewater generation in many developing regions of the world (Foster and Chilton, 2004). The range of potential groundwater pollutants from wastewater infiltration includes pathogenic micro-organisms, excess nutrients and dissolved organic carbon (Ronen et al., 1987) and, particularly where a significant component of industrial effluent is present, toxic heavy metals and xenobiotic organic compounds (Foster and Chilton, 2004). At a greater detail, the actual effect on groundwater quality can vary widely depending upon a number of factors, including, but not limited to, the following:

- the pollution vulnerability of the aquifer;

- the quality of the native groundwater and its potential use;

- the origin of the sewage effluent;

- the quality of wastewater, and its level of treatment and dilution;

- the scale of wastewater infiltration compared with that of aquifer through flow.

In karst areas, due to hydrogeological peculiarity of the environment, and namely to the presence of near-surface fractured and karstified aquifers, there is likely to be significant penetration of pathogenic bacteria and viruses to aquifers (Aller et al., 1987; White, 1988; Emmett and Telfer, 1994; Frumkin, 1999; Plagnes and Bakalowicz, 2002).

Uncontrolled urban sewage effluent and industrial discharges in lakes and rivers, and the intensive use of pesticides and herbicides in agriculture, are causing in Albania increasingly widespread degradation of aquifers, and decrease of the good quality of water in karst areas. Some examples, among the many present in the Albanian territory, may help in illustrating the heavy consequences of anthropogenic actions on the quality of groundwater in karst areas. In the Burrel region, nearby the village of Krasta, the waste products from a firm have been wasted in karst depressions, without performing any action to prevent the likely pollution. The wastes, rich in chromium, have been transported in the Mati River, which waters are intensively used to irrigate the fields. In addition, some springs, which feed aqueducts for several rural villages, are located nearby, and thus potentially affected by polluting substances.

Using karst landforms (mostly dolines) to extract materials, on one hand, and to waste disposals, on the other, is a quite frequent practice (Atalay, 1997; Delle Rose and Parise, 2003). Dolines filled with terre rosse and bauxites are often object of excavations, and the resulting deep depressions are successively filled with solid wastes of various types, as in the case of the Polis e Dajt Mountains, and in the region of Mali i Gjere, near Gjirokaster, or at the villages of Progonat and Golem in the Kurvelesh Mountains. Exploitation of karst filling deposits, and use of karst landforms as illegal dumping cause heavy degradation in the landscape, with loss of the natural morphological setting, and pollution which may rapidly reach the underground waters. Even in rural areas, far from industrial activities and firms, events of pollution may be registered in consequence of the habit to abandon animal carcasses in dolines and karst shafts (Parise and Pascali, 2003).

The problems are still greater in those areas which were occupied by military settlements and deposits during the Communist period: abandoned weapons and equipments, together with batteries and further high-polluting materials are easily found, even in areas such as Mali me Gropa, which is the zone from where the Tirana aqueduct starts. There, the springs of Selita, Shënmëeia, Guri i Bardhë, Pëllumbas, located at the boundaries of the massif, some $60 \mathrm{~km}$ east of Tirana, are at high risk of pollution. Even though the area is of high interest as regards surface and subterranean karst, many sites on the massif are polluted or have been degraded.

Prespa $e$ Vogel is a tectono-karstic lake located in the Korça region of south-eastern Albania. During the 70's, the water of the lake has been intensively used to irrigate the Devolli plain. To allow continue irrigation, during the winter seasons the water from the river Devolli was directed into the lake by means of electrical pumping. This activity caused in a time span of few years deposition of significant amounts of solid material in the lake $\left(40000 \mathrm{~m}^{3}\right.$ alluvial deposits per year; Krutaj, 1997). Today great part of the lacustrine basin is filled with alluvial deposits, and occupied by marsh and aquatic plants. Even some springs (Mancurisht, Proger, Zvezde), which waterflow was related to the lake, are now lost, or present a very limited discharge.

Additional situations, where intervention of man has modified the natural hydric regime and/or caused pollution, are also present at other lakes at the boundaries between Albania, Macedonia and Greece, as Prespa e Madhe, and at the Skutari tectono-karstic plain, in north-western Albania, 


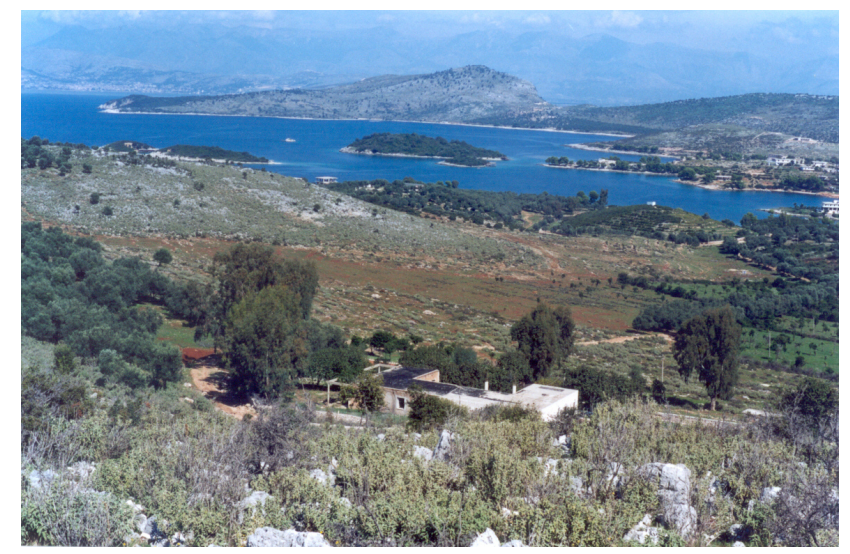

Fig. 8. View of the albanian coast south of Saranda: this stretch of the Adriatic Sea is polluted due to wastewater from the Ksamil village (visibile in the photo) and from the military buildings shown in the foreground.

where in many villages a high pollution of groundwater is present, with serious consequences on the public health. In the Koplik area, for example, the use of water from wells has repeatedly produced in the past diffusion of epidemies.

Even as regards groundwater pollution, the political and social changes occurred in Albania did not change much the situation during the transitory period: on the contrary, since subterranean water was used without any restriction, and industrial remnants discharged underground, the quality of water in karst areas strongly degraded. A further problem, on which up today very few data are available, is represented by sea water intrusion in coastal karst areas, due to excessive pumping from wells. Sea water intrusion is a very serious problem along many coasts of the Mediterranean, and has been intensively studied, for example, in the Apulian karst of southern Italy (Cotecchia et al., 1983; Delle Rose et al., 2003). Located exactly in front of Apulia, at the other end of the Adriatic Sea, Albania too has long stretches of coast where carbonate rocks crop out, and wide coastal plains characterized by marsh and palustrine lands, as in Apulia (Delle Rose and Parise, 2002). All of these areas, in consequence of the increasing population moving toward the coast, because of the attempt to launch tourist exploitation of the sites, are likely to be involved in the next years by sea water intrusion problems, if the exploitation of groundwater resources is not performed adequately (Selenica, 1998). In addition to sea water intrusion problems, events of pollution have been registered at many sites, due to mismanagement of the environment (Fig. 8).

\subsection{Loss of karst landscape}

Albania is a country with high presence of karst caves, due to diffuse outcropping of soluble rocks. Even though many caves have been explored, surveyed, and documented (often by speleological expeditions from abroad, in particular from Italy; Brasellari, 1993; Marzolla and Gambari, 1994; Bassi

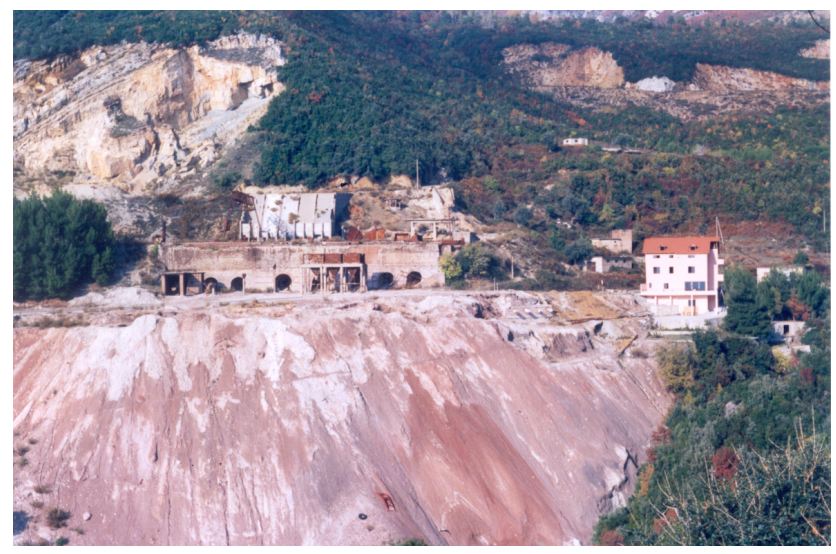

Fig. 9. Quarry facilities which were active during the Communist period for lime production from limestones of Burdigalian age. The quarry is located close to the village of Linxe, in the Dajt province, just east from Tirana. Wastes from the activity were discharged in the Tirana river, running just below, and some of its main tributaries.

et al., 1999; Savino et al., 2003), and a number of about 1000 caves is today estimated in Albania, a complete inventory of the Albanian caves is not yet available. Recently, within the framework of a bi-lateral project of cooperation between Italy and Albania (Project "Karst ecosystems of Albania Values and risks - Problems of management for a sustainable development"; Scientific Responsibles: P. Qiriazi for Albania, M. Parise for Italy), an attempt in creating a preliminary list of caves in Albania has started.

The first, and most serious, consequence of the lack of inventory of the albanian caves, is that many of them have been destroyed, or severely damaged and/or polluted, by man. Several anthropogenic activities are in fact responsible of karst cave destruction, including mining, quarrying, uncontrolled exploitation of hydric resources, etc. (Legrand, 1984; Nicod, 1991; Hardwick and Gunn, 1993; Memon et al., 2002).

The extraction of limestones through quarrying activity inevitably has dramatic impacts on the karst landforms (Gillieson, 1996; Gunn and Bailey, 1993). Increasing use of explosives transformed quarrying in the most severe anthropogenic impact in karst areas, even due to location of many quarries in areas of high scenic value and/or of considerable scientific interest (Fig. 9). Impact of quarrying in karst areas is not limited to the direct activity of extraction: removing of the subcutaneous zone, that is the area in which the majority of limestone solution takes place and where a substantial proportion of groundwater may be stored (Gunn, 1986; Delle Rose and Parise, 2003), represents a further, significant, problem. In addition, total destruction of the existing ecosystems as a result of stripping of soil, grassland and woodland, and destruction of cave passages and their deposits, have also to be considered. Last but not least, quarrying, if not followed by quarry reclamation, results in prominent, anti-aesthaetic, anthropogenic landforms which can be present for thousands of years in the landscape. 


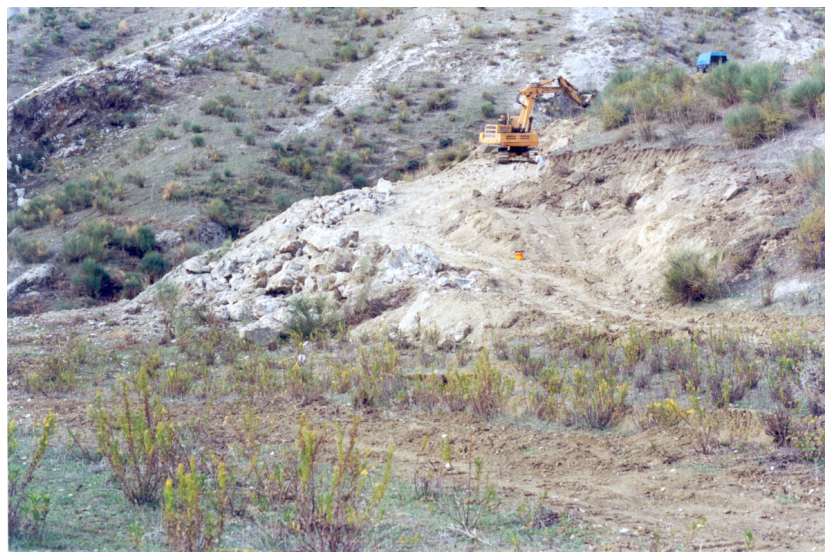

Fig. 10. Gypsum and alabaster mining areas near the village of Mëngaj (Kavaje district). Messinian evaporites have been the object of intensive extraction, without considering the presence of several karst caves, some of which have been destroyed by the mining activity. Protests from environmentalists and scientists eventually resulted in stopping the activities, thus saving at least a karst cave located few tens of meters apart from where the caterpillar is (northwestern corner of the photo).

Among the many examples of karst caves which have been lost due to quarrying, the following case is worth to be mentioned. The Shahinova cave was located near the town of Berat, north of Mount Shpirag; discovered during quarrying activity, the cave had great naturalistic importance (Fistani et al., 1997). Continuing activity of limestone extraction, however, caused the complete destruction of the Shahinova cave, and of many other minor karst cavities nearby. This situation is common to many other sites in Albania. Even in areas which, due to peculiarity of the natural environment, are declared national monuments or park, quarrying resulted in loss of many caves, and in degradation of the landscape as well. In fact, it is common practice to abandon the site of extraction without any sistemation and/or reclamation work is carried out. This also results in potential danger because of the many unstable blocks left on the slopes, likely to be involved in landsliding. The valley of the Tirana River, and the Dajti National Park, are two examples at this regard.

Evaporite rocks are object of quarrying, too: few years ago, in the area of Mengaj, a small village close to the town of Kavaja, where Messinian evaporites extensively crop out, works to extract gypsum started. Several dolines were soon canceled, until the front of excavation reached the entrance of a cave (Fig. 10). Even though the intention was to proceed quarrying, with no concern for the cave, which was going to be destroyed, in this case the protest arised from environmentalists, local inhabitants and researchers was successful in stopping the activity. This was, however, a very unique example. Many other caves in evaporite rocks had been lost, at Mengaj, in the Dumre district, and at other sites.

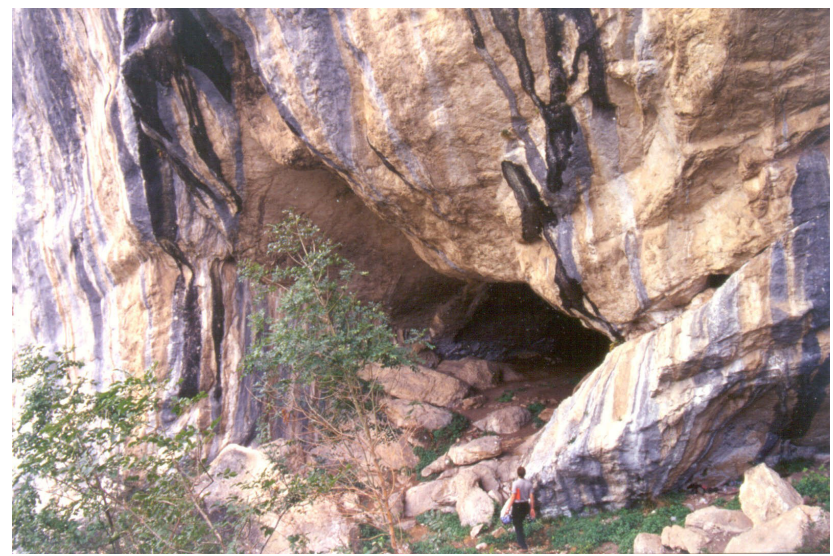

Fig. 11. Entrance of the cave Shpella ë zeze, important site for karst, paleontological and archaeological researches.

In some cases, the destruction was related to military activity: in the Mirdita area, for example, the caves Shutre and Merkurth were chosen as sites to store weapons. In order to enlarge the natural cave environment, and have therefore larger room available for weapons stockage, explosives were used. Later, the caves were abandoned, but the effects deriving from the explosions are still visible today. Even where the caves were exploited to supply water to towns and villages, the entrance of the caves were often damaged, as occurred at the Vanistra cave near Gjirokaster, and at the Krevenica cave near Koplik.

Many Albanian caves have great scientific importance, due to archaeological, palaeontological, geological, and prehistorical findings and discoveries. However, the lack of an environmental consciousness, together with the absence of control from authorities, led to loss of many findings, damage to caves and cave sediments, up in some cases to complete cave destruction. Even when an attempt has been made to protect and safeguard the natural subterranean karst heritage, this was generally unsuccessful. The Black Cave (Shpella ë zeze; Fig. 11), located at the left wall of the canyon of river Erzen, some $25 \mathrm{~km}$ south-east of Tirana, hosted remains of Ursus spelaeus, and was inhabited by man in prehistoric time. For this reason, and also considering the relative vicinity to Tirana, a project of exploitation of the cave, including the realization of a museum with didactical and tourist aims, was proposed by a group of scientists (Qiriazi et al., $1995^{1}$ ). Unfortunately, the project was not approved, and the cave is still today without protection.

The caves explored during the many speleological expeditions carried out in Albania often present problems related to pollution and degradation, affecting both the cave and their deposits, and the aquifers contained therein. The problems may become very serious when the caves are located close to villages, or used to exploit water for the people, as in the case

\footnotetext{
${ }^{1}$ Qiriazi, P., Bego, F., and Prifti, K.: Turning the Black Cave (Shpella e zeze) into a geological, archaeological and paleontological museum, Tirana, unpublished report, 1995.
} 


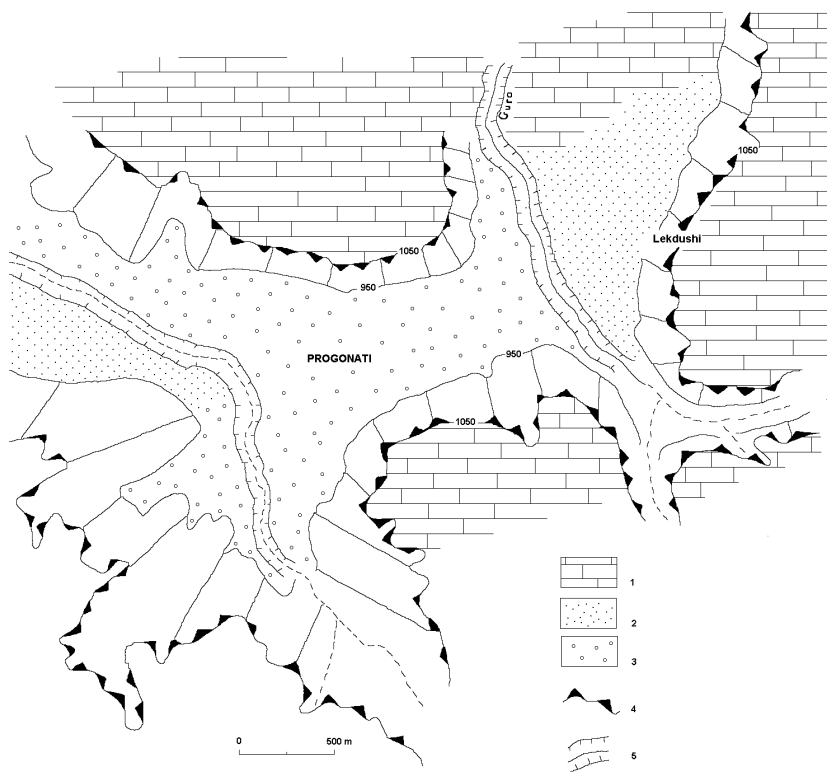

Fig. 12. Geomorphological sketch of the Progonat area, in the Kurvelesh Massif (simplified after Krutaj, 1985). Explanation: 1) limestones; 2) hummocky surface; 3) flat land; 4) scarp; 5) canyon.

of Shpella Mema ë Ujit, at the contact between limestones and one of the many chert levels which characterizes the carbonate rocks of the Kurvelesh Massif; the water coming from this cave is used for supply the village of Lekdushi, close to Progonat (Fig. 12). In this area, some of the most remarkable example of Albanian caves have been found, including Shterra ë Cikes (Fig. 13) and Shterra ë Shankoll (Savino et al., 2003). However, it has again to be stressed that many areas in Albania have a very high potential of karstification, and thus present caves and karst landscape worth to be studied and protected. For many karst areas of Albania, in fact, very scarce documentation about surface and underground karst exists still today.

\section{Discussion}

Many hazards of both natural and anthropogenic origin affect karst terrains, due to intrinsic high vulnerability of the environment, which combines with the actions performed by man (increasing urbanization, advances in agriculture technologies, etc.). The latter, especially in developing countries, are generally accomplished through great changes and transformation of the natural landform. Management of karst is thus particularly difficult. However, attempts toward a sustainable development of these areas have to be performed, to avoid irrevocable loss of precious environments and resources.

A special care has to be addressed toward the search of an equilibrium between development of new technologies and their implementation in agricultural activities, and the response of the natural landscape to any land-use change (Re-

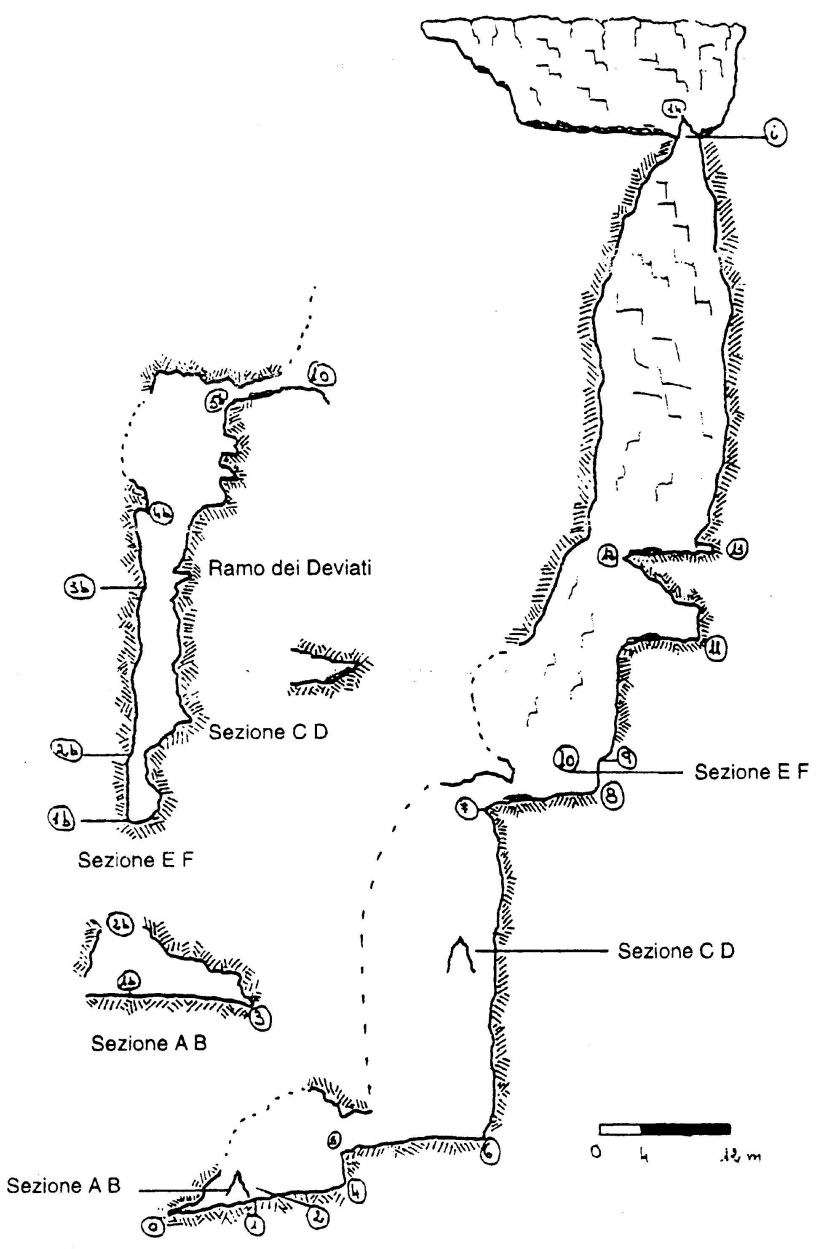

Fig. 13. Survey of the cave Shterra $\ddot{e}$ Cikes (after Savino, 1995; exploration performed by cavers from Gruppo Puglia Grotte and Gruppo Speleologico Dauno). The cave, $112 \mathrm{~m}$ deep, was one of the most interesting explored during the speleological expedition "Kurvelesh '94".

jec Brancely, 1998; Gams and Gabrovec, 1999; Calder et al., 2004). The process, active since some decades, of loss of forests and wood lands to transform karst landscape in cultivable fields, too often has revealed itself as the first step toward land degradation, later abandonment of the recently gained terrains to agriculture fields, increase of the erosion rate and of mass movements on slopes, until, eventually, desertification.

Even more than for agricultural activities, the value of karst as source of hydric resources has to be considered. Carbonate rocks are in fact hydrogeologically of extreme importance, since limestone and dolomite form very important aquifers from both a quantitative and qualitative point of view (Jordana and Batista, 2004). This makes karst one of the geological settings more favourable to presence of good quality water resources On the other hand, it has to be considered the fragility of the karst environment, where it may be very easy to carry out actions of pollution of the karst aquifers. 
At this latter regard, protection and preservation of karst caves has also to be considered: the connectivity between surface and subsurface settings in a karst environment allows, in fact, any negative action which is carried out at the ground surface to be transferred, with all of its potential danger, underground (Parise and Pascali, 2003). This has the main effect on groundwater pollution. In karst, as well as in other settings, the sustainability of groundwater is closely linked with a range of micro- and macro-policy issues influencing land-use and surface water, and represents one of the major challenges in natural resource management (Gunay and Ekmekci, 1997; Kemper, 2004). As it was recently observed, "in developing countries, groundwater scarcity and pollution disproportionately affect the poor because they are often not able to keep up with sinking groundwater levels or to find alternative sources when their groundwater resource becomes polluted" (Kemper, 2004, p. 3).

In the case of Albania, there is a great availability of highquality groundwater resource from karst areas, but a high risk of pollution of these resources exists: if a policy of protection and safeguarding will not start effectively very soon, there is a high chance of pollution and/or overexploitation of water. Since these events may be particularly dramatic, often producing irrevocable damage (Yair, 1983; Parise, 2001), a strong need for planning in karst develops, as observed in several similar areas in the world (Fischer et al., 1987; Quinlan and Alexander, 1987; Williams, 1993; White, 2002). The expected expansion of the population in the main Albanian towns, coupled with the numerous human activities threatening the groundwater quality, make necessary to manage in new ways the urban activities in order to keep the precious groundwater resource. Reduced discharge of polluted water to the environment from households and utilities, for example, conserves the quality of groundwater and reduces sophisticated treatment costs (Drangert and Cronin, 2004).

Loss of quality of the natural groundwater may have, on the other hand, immediate effects on health, especially in areas where a strong increase in population, often not coupled with the necessary hydraulic and hygienic works, occurs (Jordana and Batista, 2004). The study and control of the natural groundwater quality appears therefore to be fundamental in developing countries. As the available resources of freshwater decrease due to pollution and over-exploitation, and the need of water increases, more efforts have to be devoted to guarantee water quality. This is particularly true for countries as Albania, where many additional problems are related also to water distribution: old age of the system, and illegal connections to it result in fact in great losses of the network distribution, at the same time making possible situations of pollution. Again, the need in creating in the population an awareness about environmental problems highlights. This appears to be a very slow, but necessary, process to reach protection of the karst environment and to perform sustainable development and use of the many resources it presents.
Acknowledgements. This work has been carried out within the framework of the project of Scientific and Technological Cooperation between Albania and Italy: "Karst ecosystems of Albania - Values and risks - Problems of management for a sustainable development".

Edited by: J. Gunn

Reviewed by: one referee

\section{References}

Akdim, B. and Amyay, M.: Environmental vulnerability and agriculture in the karstic domain: landscape indicators and cases in the Atlas Highlands, Morocco, Int. J. Spel., 26 B (1/4), 119-138, 1999.

Aliaj, S.: Transverse faults in Albanian orogen front, Albanian J. Nat. Techn. Sciences, 6, 121-132, 1999.

Aliaj, S., Baldassarre, G., and Shkupi, D.: Quaternary subsidence zones in Albania: some case studies, Bull. Eng. Geol. Env., 59, 313-318, 2001

Aller, L., Bennet, T., Lehr, J. H., Petty, R. J., and Hackett, G. DRASTIC: a standardized system for evaluating ground water pollution potential using hydrogeologic settings, NWWA/EPA Ser., EPA 600/2-87-035, 1987.

Atalay, I.: Red Mediterranean soils in some karstic regions of Taurus Mountains, Turkey, Catena, 28, 247-260, 1997.

Atalay, I.: Land use in the karstic lands in the Mediterranean region, Int. J. Spel., 26 B (1/4), 111-118, 1999.

Baboci, K., Palmentola, G., and Sansò, P.: Primi risultati dello studio quantitativo delle forme carsiche epigee nei dintorni di San Marco in Lamis (FG), Itinerari Speleologici, 5, 87-95, 1991.

Bassi S., Fabbri I., and Scaravelli, D.: Speciale Albania, Ipogea, 39-63, 1999.

Benito, G., Gutierrez, M., and Sancho, C.: Erosion rates in badland areas of the Central Ebro Basin (NE Spain), Catena, 19, 269286, 1992.

Brasellari, S.: Karst in Albania (Kras y Albanii), Speleoforum, Ceska Spel. Spolecnost, Brno, 93, 54-58, 1993.

Burri, E., Castiglioni, B., and Sauro, U.: Agriculture, landscape and human impact in some karst areas of Italy, Int. J. Spel., 26 B (1/4), 33-54, 1999.

Calder, I., Amezaga, J., Aylward, B., Bosch, J., Fuller, L., Gallop, K., Gosain, A., Hope, R., Jewitt, G., Miranda, M., Porras, I., and Wilson, V.: Forest and water policies. The need to reconcile public and science perceptions, Geologica Acta, 2 (2), 157-166, 2004.

Cooper, A. H.: Halite karst geohazards (natural and man-made) in the United Kingdom, Environ. Geol., 42, 505-512, 2002.

Cooper, A. H. and Waltham, A. C.: Subsidence caused by gypsum dissolution at Ripon, North Yorkshire, Quart. J. Eng. Geol., 32, 305-310, 1999.

Cotecchia, V., Tadolini, T., and Tulipano, L.: Sea water intrusion in the planning of groundwater resources protection and utilization in the Apulia region (southern Italy), Geol. Appl. e Idrog., 18 (2), 367-382, 1983.

Delle Rose, M. and Parise, M.: Karst subsidence in south-central Apulia, southern Italy, Int. J. Spel., 31 (1/4), 181-199, 2002.

Delle Rose, M. and Parise, M.: Land use and human impact in the Mediterranean karst of southern Italy, Geophysical Research Abstracts, 5, no. 03376, 2003. 
Delle Rose, M., Fidelibus, C., Internò, G., and Parise, M.: The experience of southern Apulia (Italy) coastal karst aquifer: indications for the management, in: Sustainable planning and development, edited by: Beriatos, E., Brebbia, C. A., Coccossis, H., and Kungolos, A., Proc. 1st Conf., 1-3 October 2003, Skiathos (Greece), WIT Press, 453-461, 2003.

Delle Rose, M., Federico, A., and Parise, M.: Sinkhole genesis and evolution in Apulia, and their interrelations with the anthropogenic environment, Natural Hazards and Earth System Sciences, in press, 2004

Diamnti, F.: Formacioni evaporitik në Shqipëri, mundësia e kurthëzimeve hidrokarbureve dhe e kërkimit të mineraleve të tjerë të debishëm, Buletini i Shkenrave Gjeologjike, 2, 2002.

Drangert, J. O. and Cronin, A. A.: Use and abuse of the urban groundwater resource: implications for a new management strategy, Hydrogeology Journal, 12, 94-102, 2004.

Dunne, T.: Problems in measuring and modelling the influence of forest management on hydrologic and geomorphic processes, in: Land use and watersheds, edited by: Wigmosta, M. S. and Burges, S. J., American Geophysical Union, 77-85, 2001.

Eftimi, R. and Tafilaj, I.: Preliminary assessment of the possible land subsidence in Turani well field - Korca city, Proc. UNESCO-BAS Int. Proj. "Expert Assessment of Land Subsidence Related to Hydrogeological and Engineering Geological Conditions in the Regions of Sofia, Skopje and Tirana", 4th Work. Group Meeting, 75-81, 1999.

Emmett, A. J. and Telfer, A. L.: Influence of karst hydrology on water quality management in southeast South Australia, Environ. Geology, 23, 149-155, 1994.

Enne, G., Pulina, G., D’Angelo, M., Previtali, F., Madrau, S., Caredda, S. and Francesconi, A. M. D.: Agro-pastoral activities and land degradation in Mediterranean areas: case study of Sardinia, in: Mediterranean desertification. A mosaic of processes and responses, edited by: Geeson, N. A., Brandt, C. J., and Thornes, J. B., John Wiley and Sons, 71-81, 2002.

Fischer, J. A., Greene, R. W., Ottoson, R. S., and Graham, T. C.: Planning and design considerations in karst terrain, Proc. 2nd Multidisciplinary Conf. on Sinkholes and the Environmental Impacts of Karst, Orlando, 9-11 February 1987, 323-329, 1987.

Fistani, A. B., Pavlakis P. P., and Symeonidis N. S.: First Discovery of Hysterix primigenia Wagner from the Late Miocene Pliocene deposits of Shahinova, Berat, South-West Albania, Ann. Naturhist. Mus. Wien, 98 A, 155-172, 1997.

Foster, S. S. D. and Chilton, P. J.: Downstream of downtown: urban wastewater as groundwater recharge, Hydrogeology Journal, 12, $115-120,2004$.

Frumkin, A.: Interaction between karst, water and agriculture over the climatic gradient of Israel, Int. J. Spel., 26 B (1/4), 99-110, 1999.

Gams, I. and Gabrovec, M.: Land use and human impact in the Dinaric Karst, Int. J. Spel., 26 B (1/4), 55-70, 1999.

Gerrard, J.: Soil geomorphology, Chapman \& Hall, London, 269, 1992.

Giglio, G., Moretti, M. and Tropeano, M.: Rapporto fra uso del suolo ed erosione nelle Murge Alte: effetti del miglioramento fondiario mediante pratiche di "spietramento", Geol. Appl. e Idrog., 31, 179-185, 1996.

Gillieson, D.: Caves, Blackwell Publishers, Oxford, 324, 1996.

Gillieson, D. and Thurgate, M.: Karst and agriculture in Australia, Int. J. Spel., 26 B (1/4), 149-168, 1999.

Guerrero, J., Gutierrez, F., and Lucha, P.: Paleosubsidence and active subsidence due to evaporite dissolution in the Zaragoza area
(Huerva River valley, NE Spain): processes, spatial distribution and protection measures for transport routes, Engineering Geology, 72, 309-329, 2004.

Gunay, G. and Ekmekci, M.: Importance of public awareness in groundwater pollution, Proc. 5th Int. Symp. and Field Seminar on "Karst Waters \& Environmental Impacts", Antalya (Turkey), 10-20 Sept. 1995, 3-10, 1997.

Gunn, J.: Solute processes and karst landforms, in: Solute processes, edited by: Trudgill, S. T., John Wiley and Sons, 363-437, 1986.

Gunn, J. and Bailey, D.: Limestone quarrying and quarry reclamation in Britain, Environmental Geology, 21 (3), 167-172, 1993.

Gutierrez, F.: Gypsum karstification induced subsidence: effects on alluvial systems and derived geohazards (Calatayud Graben, Iberian Range, Spain), Geomorphology, 16, 277-293, 1996.

Gutierrez, F., Ortì, F., Gutierrez, M., Perez Gonzalez, A., Benito, G., Prieto, J. G., and Duran Valsero, J. J.: The stratigraphical record and activity of evaporite dissolution subsidence in Spain, Carbonates and Evaporites, 16 (1), 46-70, 2001.

Hardwick, P. and Gunn, J.: The impact of agriculture on limestone caves, Catena, 25, 235-250, 1993.

Haska, H., Dida, M., and Ypi, Z.: Sustainable management of forest and pasture ecosystems for preventing soil degradation, Proc. Nat. Conf. "Land Degradation and Protection in Albania", Tirane, 22-23 April 2003, abstract volume, 2003.

Holland, E.: The effects of fire on soluble rock landscapes, Helictite, 32 (1), 3-9, 1994.

Institute Hydrométéorologique: The hydrology of Albania, (in albanian), 1985 .

Jordana, S. and Batista, E.: Natural groundwater quality and health, Geologica Acta, 2 (2), 175-188, 2004.

Kemper, K. E.: Groundwater from development to management, Hydrogeology Journal, 12, 3-5, 2004.

Kosmas, C., Danalatos, N. G., Lopez-Bermudez, F., and Romero Diaz, M. A.: The effect of land use on soil erosion and land degradation under Mediterranean conditions, in: Mediterranean desertification. A mosaic of processes and responses, edite by: Geeson, N. A., Brandt, C. J., and Thornes, J. B., John Wiley and Sons, 57-70, 2002.

Kovaci, V., Rakacolli, Z., and Dedaj, K.: Soil erosion, factors, parameters and measures for the soil protected, Proc. Nat. Conf. "Land Degradation and Protection in Albania", Tirane, 22-23 April 2003, abstract volume, 2003.

Kristo, V.: The features of the karstic relief in the plateau of Dumrea and its development conditions, (in Albanian), Studime Gjeografike, 5, 107-115, 1994.

Kristo, V., Krutaj, F., and Mezini, B.: Karst landscape of Albania and the problems of its rational exploitation, (in Albanian), Studime Gjeografike, 2, 257-268, 1987.

Krutaj, F.: Some features typical of the karst morphology at Kurvelesh, (in Albanian), Studime Gjeografike, 1, 48-67, 1985.

Krutaj, F.: Morphology and karstic ecosystem in the area of Ohri and Prespa lakes, Proc. Int. Symp. Korca, Albania, 1997.

Legrand, H. E.: Environmental problems in karst terranes, in: Hydrogeology of karstic terrains - Case histories, edited by: Burger, A. and Dubertret, L., Int. Ass. Hydrogeologists, 1, 189-194, 1984.

Manzano, M. G. and Navar, J.: Processes of desertification by goats overgrazing in the Tamaulipan thornscrub (matorral) in northeastern Mexico, J. Arid Environ., 44, 1-17, 2000.

Marzolla, G. and Gambari, S.: Prima ricognizione speleologica in Albania (maggio 1989), Notiziario del Circolo Speleologico Ro- 
mano, 4-5, 97-117, 1994.

Memon, B. A., Azmeh, M. M., and Pitts, M. W.: The environmental hazards of locating wastewater impoundments in karst terrain, Engineering Geology, 65 (2-3), 169-177, 2002.

Nicod, J.: Natural hazards and engineering impacts in the karst of Mediterranean France, Proc. Int. Conf. on Environmental Changes in Karst Areas, 15-27 September 1991, 9-16, 1991.

Nicod, J. and Salomon, J. N.: Impacts of agricultural transformation on the principal karst regions of France, Int. J. Spel., 26 B (1/4), 15-31, 1999.

Parise, M. (Ed): Gestione e salvaguardia delle falde acquifere in ambiente carsico, Proc. Round Table "Waters of the Third Millennium", Castellana-Grotte, 31 March 2001, Grotte e Dintorni, 2, 96, 2001.

Parise, M.: Flood history in the karst environment of CastellanaGrotte (Apulia, southern Italy), Natural Hazards and Earth System Sciences, 3 (6), 593-604, 2003,

\section{SRef-ID: 1684-9981/nhess/2003-3-593.}

Parise, M. and Pascali, V.: Surface and subsurface environmental degradation in the karst of Apulia (southern Italy), Environmental Geology, 44, 247-256, 2003.

Parise, M., Qiriazi, P., Sala, S., and Cara, G.: Problemi di gestione e salvaguardia di ecosistemi carsici in Albania, Proc. 19th Nat. Congr. Spel., Bologna, 27-31 August 2003, 105-114, 2003.

Plagnes, V. and Bakalowicz, M.: The protection of a karst water resource from the example of the Larzac karst plateau (south of France): a matter of regulations or a matter of process knowledge?, Engineering Geology, 65 (2-3), 107-116, 2002.

Qiriazi, P.: Gjeografia fizike e Shqiperise, Aferdita, Tirane, 367, 2001.

Qiriazi, P. and Sala, S.: The mass movements in Albania and the human activities, Transactions Japanese Geomorphological Union, 20 (3), 251-264, 1999.

Qiriazi, P. and Sala, S.: Environmental problems of Albania, in: Remote sensing for environmental data in Albania: a strategy for integrated management, edited by: Buchroithner, M. F., Kluwer, 13-30, 2000.

Qiriazi, P., Parise, M., and Sala, S.: Il carsismo nei gessi del territorio albanese, Proc. Int. Symp. "Gypsum Karst Areas in the World. Their Protection and Tourist Development", 26-28 August 2003, Bologna, 2004.

Quinlan, J. F. and Alexander Jr., E. C.: How often should samples be taken at relevant locations for reliable monitoring of pollutants from an agricultural, waste disposal, or spill site in a karst terrane? A first approximation, Proc. 2nd Multidisciplinary Conf. on Sinkholes and the Environmental Impacts of Karst, Orlando, 9-11 February 1987, 277-286, 1987.

Rejec Brancelj, I.: Influence of modern farming on karstic landscapes, Acta Carsologica, 27/1 (3), 201-213, 1998.

Ronen, D., Magaritz, M., Almon, E., and Aimal, A. J.: Anthropogenic anoxification (eutrophization) of the water-table region of a deep phreatic aquifer, Water Resources Research, 13, 1554$1560,1987$.
Sala, S., Fusilli, C., Didonna, F., Eugenelo, A., and Savino G.: Underground karst in the Mountain of Polisi, (in albanian), Studime Gjeografike, 7, 15-18, 1994.

Sauro, U.: Human impact on the karst of the Venetian Fore-Alps (Southern Alps, Northern Italy), Environ. Geol., 21/3, 115-121, 1993.

Savino, G.: Kurvelesh '94: alcuni aspetti di una spedizione speleologica in Albania, Puglia Grotte, 7-13, 1995.

Savino, G., Di Donna, F., Parise, M., and Sgobba, D.: La ricerca speleo-carsica in Albania: risultati e prospettive, Thalassia Salentina, 26, 33-40, 2003.

Selenica, A.: Present water uses and their evolution in the framework of national water strategy for Albania, Albanian Journal of Natural \& Technical Sciences, 5, 131-137, 1998.

Sharma, K. D.: The hydrologic indicators of desertification, J. Arid Environ., 39, 121-132, 1998.

Thornes, J. B.: The evolving context of Mediterranean desertification, in: Mediterranean desertification. A mosaic of processes and responses, edited by: Geeson, N. A., Brandt, C. J., and Thornes, J. B., John Wiley and Sons, 5-11, 2002.

Tulipano, L., Tadolini, T., and Fidelibus, D.: Pollution of groundwater in a carbonatic and karstic aquifer due to urban effluent and agricultural activities, Proc. Int. Symp. on Impact of Agricultural Activity on Ground Water, Prague, 16 (I), 395-411, 1982.

UNEP: Desertification revisited: proceedings of an ad hoc consultative meeting on the assessment of desertification, UNEP/DC/PAC, Nairobi, 289-294, 1990.

White, W. B.: Geomorphology and hydrology of karst terrains, Oxford University Press, 464, 1988.

White, W. B.: Karst hydrology: recent developments and open questions, Engineering Geology, 65 (2-3), 85-105, 2002.

Williams, P. W.: Environmental change and human impact on karst terrains: an introduction, in: Karst terrains: environmental changes and human impact, edited by: Williams, P. W., Catena, suppl. 25, 1-20, 1993.

Williams, P.: Dolines, in: Encyclopedia of caves and karst science, edited by: Gunn, J., Routledge, 304-310, 2003.

Yair, A.: Hillslope hydrology, water harvesting and areal distribution of some ancient agricultural systems in the northern Negev Desert, J. Arid Environ., 6, 283-301, 1983.

Yair, A.: The ambiguous impact of climate change at a desert fringe: Northern Negev, Israel, in: Environmental change in drylands: biogeographical and geomorphological perspectives, edited by: Millington, A. C. and Pye, K., John Wiley \& Sons Ltd., 199227, 1994.

Yair, A., Goldberg, P., and Brimer, R.: Long term denudation rates in the Zin-Havarim badlands of northern Negev, Israel, in: Badlands geomorphology and piping, edited by: Bryan, R. and Yair, A., Geobooks Norwich, 279-291, 1982. 